\title{
Intra-pituitary regulation of gonadotrophs in male rodents and primates
}

\author{
Stephen J Winters and Joseph P Moore \\ Division of Endocrinology, Metabolism and Diabetes, University of Louisville, ACB-A3G11, 550 Jackson Street, \\ Louisville, Kentucky 40202, USA
}

Correspondence should be addressed to Stephen J Winters; Email: sjwint01@louisville.edu

\begin{abstract}
Paracrine and autocrine regulation is well established in many organs including the gonads, but the notion of communication among pituitary cells is a relatively new concept. The FSH- $\beta$ and $\mathrm{GnRH}$-receptor genes are up-regulated by pituitary activin and down-regulated by pituitary follistatin, and circulating inhibin disrupts this local regulation by functioning as an endogenous competitor of the activin receptor. Activin and follistatin production by folliculostellate cells may play a central role in these responses. $\alpha$-Subunit expression is maintained at high levels in the absence of $\mathrm{GnRH}$ through unknown mechanisms. There is evidence that the intra-pituitary regulation of FSH- $\beta$ and GnRH-receptor gene expression may activate pubertal maturation in male rats. Finally, there are marked differences in follistatin expression and its regulation by GnRH and androgens in male primates and rats that appear to explain species differences in the differential secretion of FSH and $\mathrm{LH}$, although the physiological significance of these differences is not yet known.

Reproduction (2004) 128 13-23
\end{abstract}

\section{Introduction}

Gonadotropin-releasing hormone (GnRH), a decapeptide from the hypothalamus, is the proximate regulator of gonadotroph function (Stojilkovic \& Catt 1995, Cheng \& Leung 2000, Kakar et al. 2002). It is becoming increasingly evident, however, that gonadotrophs are also regulated by factors produced by gonadotrophs themselves, or by surrounding pituitary cells, that generate unique effects or influence the actions of $\mathrm{GnRH}$. Table 1 lists proposed autocrine and paracrine regulators of gonadotrophs. For the most part, these substances have been identified because their receptors are expressed by gonadotrophs, or through effects they produce when added to pituitary cell cultures; the physiological role of most of these factors remains to be elucidated. Microarray analysis has identified over 200 genes in gonadotrophs that are regulated by GnRH (Kakar et al. 2003). In this review we will examine the intra-pituitary regulation of the gonadotropin subunit and GnRH-receptor (GnRH-R) genes since much is known about these genes, and they are essential for reproduction.

While early studies sought to identify a unique hypothalamic follicle-simulating hormone (FSH)-releasing factor to explain instances in which $\mathrm{FSH}$ and luteinizing hormone (LH) secretion diverge, it is now evident that FSH secretion is selectively regulated because $\mathrm{FSH}-\beta$ gene expression is increased by activin, or decreased by follistatin or inhibin.
Moreover, these factors regulate GnRH-receptors. There is evidence that activin and follistatin are produced by gonadotrophs and by pituitary folliculostellate cells, and perhaps by somatotrophs, lactotrophs and thyrotrophs. Inhibin, a product of the testis, may also be produced in small amounts in the pituitary. There are several recent reviews describing activin, follistatin and inhibin signaling (Itoh et al. 2000, Pangas \& Woodruff 2000, Gray et al. 2002). Our focus will be to integrate that information with what is known about FSH- $\beta$ and GnRH-receptors, to discuss the paracrine control of the gonadotropin subunits and GnRH-receptors during pubertal development in the male rat, and to highlight differences in the regulation of these genes in male primates.

\section{Activin, follistatin and inhibin}

Separation of the pituitary from GnRH stimulation in male rats abolishes LH synthesis and secretion but allows for continued production of FSH (Sheridan et al. 1979, Culler \& Negro-Vilar 1986, DePaolo et al. 1991) as well as uncombined $\alpha$-subunit (Grotjan et al. 1984). While these experiments revealed that $\alpha$-subunit and $\mathrm{FSH}-\beta$ are not entirely GnRH dependent, the initial hypothesis for a system controlling the differential regulation of the gonadotropins was derived from studies of the testis (McCullagh 1932) in which a water-soluble testicular extract prevented 
Table 1 Pituitary factors proposed to regulate gonadotrophs.

\begin{tabular}{|c|c|c|c|c|}
\hline Factor & Action & Cell source & Species & Reference \\
\hline Activin & Increase number of cells secreting FSH, amount FSH per cell & $\mathrm{G}, \mathrm{S}, \mathrm{T}$ & Rat & Miyamoto et al. 1999 \\
\hline Adenosine & Decrease FSH secretion & All & Rat & Yu et al. 1998 \\
\hline ATP & $\begin{array}{l}\text { Decrease LH, FSH secretion } \\
\text { Increase } \mathrm{Ca}^{2+} \text { entry; LH secretion } \\
\text { Increase LH secretion }\end{array}$ & All & Rat & $\begin{array}{l}\text { Picanco-Diniz et al. } 1996 \\
\text { Tomic et al. } 1996 \\
\text { Chen et al. } 1995\end{array}$ \\
\hline CNP & Increase LH secretion & G & Rat & McArdle et al. 1993 \\
\hline EGF & Increase $\mathrm{GnRH}$ binding, $\mathrm{LH}$ response to $\mathrm{GnRH}$ & $\mathrm{G}, \mathrm{L}, \mathrm{S}, \mathrm{C}, \mathrm{T}$ & Rat & Leblanc et al. 1997 \\
\hline Follistatin & Expression linked to attenuated FSH response to $\mathrm{GnRH}$ & G, FS cells & Rat & Besecke et al. 96 \\
\hline Galanin & Decreases GnRH-stimulated LH and FSH secretion & $\mathrm{L}, \mathrm{S}, \mathrm{T}$ & Rat & Todd et al. 1998 \\
\hline $\mathrm{GnRH}$ & Increase differentiation: gonadotrophs, thyrotrophs & Rathke's & Rat E11 & Heritier \& Dubois 1994 \\
\hline & Contributes to basal LH secretion & ? & $\mathrm{Rat} / \alpha \mathrm{T} 3$ & Krsmanovic et al. 2000 \\
\hline $\mathrm{GH}$ & $\begin{array}{l}\text { Increase LH, FSH secretion } \\
\text { Decrease FSH- } \beta, \text { LH- } \beta, \text { FSH protein response to GnRH }\end{array}$ & $\mathrm{S}$ & Mouse/rat & Tang et al. 1993 \\
\hline NO & Increase LH secretion & G, FS cells & Rat & Ceccatelli et al. 1993 \\
\hline NPY & Increase FSH and LH secretion & $\mathrm{L}$ & Rat & O'Conner et al. 1993 \\
\hline & Decrease LH secretion & & Rat & Bauer-Dantoin et al. 1993 \\
\hline PACAP & $\begin{array}{l}\text { Increase LH and FSH secretion } \\
\text { Decrease FSH- } \beta \text { mRNA }\end{array}$ & G, FS cells & Rat & $\begin{array}{l}\text { Culler \& Paschall } 1991 \\
\text { Winters et al. } 1997\end{array}$ \\
\hline SP & $\begin{array}{l}\text { Increase LH secretion } \\
\text { Attenuate LH, FSH responses to GnRH }\end{array}$ & $\mathrm{S}, \mathrm{T}$ & $\begin{array}{l}\text { Rat } \\
\text { Hamster }\end{array}$ & $\begin{array}{l}\text { Shamgochian \& Leeman } 1992 \\
\text { Debeliuk \& Bartke } 1994\end{array}$ \\
\hline $\mathrm{TRH}$ & Increase gonadotroph differentiation & G & Rat E11 & Heritier \& Dubois 1993 \\
\hline
\end{tabular}

G, gonadotroph; L, lactotroph; S, somatotroph; C, corticotroph; T, thyrotroph; FS cells, folliculo stellate cells; GH, growth hormone; NO, nitric oxide; NPY, neuropeptide Y; SP, substance P; TRH, thyrotropin-releasing hormone.

the formation of 'castration cells' within the anterior pituitary of orchidectomized rats. Thus began the theory that an inhibitory peptide acts as an endocrine hormone to suppress gonadotroph function. Although shrouded in controversy for many years (de Jong 1979), some 50 years later, this peptide, aptly named inhibin, was isolated from follicular fluid and demonstrated to inhibit selectively the production of FSH (De Jong 1988). Soon thereafter using similar methods, two other peptides were identified that also regulate $\mathrm{FSH}$, activin (Ling et al. 1986, Vale et al. 1986) and follistatin (Robertson et al. 1987, Ueno et al. 1987) that together established an intra-pituitary mechanism for the control of gonadotrophs.

Activins are protein dimers of two $\beta$-subunits that have been designated activin- $A\left(\beta_{A} \beta_{A}\right)$, activin-B $\left(\beta_{B} \beta_{B}\right)$ and activin- $A B\left(\beta_{A} \beta_{B}\right)$ (Vale et al. 1988). Activin-B appears to be produced by the pituitary since adding an antiserum to activin-B decreased $\mathrm{FSH}-\beta$ and $\mathrm{FSH}$ secretion (Corrigan et al. 1991) as well as activin/inhibin- $\beta_{B}$ itself and follistatin mRNA concentrations in rat pituitary cultures (Bilezikjian et al. 1996). The $\beta_{\mathrm{B}}$-subunit gene (Bilezikjian et al. 1996, Dalkin et al. 1998) and protein (Roberts et al. 1989) are also more abundant in the rat pituitary than is $\beta_{\mathrm{A}}$, and $\beta_{B}$ mRNA is found in the monkey pituitary where $\beta_{A}$ mRNA is expressed faintly (Attardi et al. 1992). Immunohistochemical studies of the human pituitary revealed $\beta_{B}$ in gonadotrophs and thyrotrophs, whereas $\beta_{\mathrm{A}}$ was localized to gonadotrophs, somatotrophs and lactotrophs (Uccella et al. 2000).

Inhibin is composed of an $\alpha$-subunit disulfide linked to one of two $\beta$-subunits, the $\beta_{A}$-subunit to form inhibin- $A$, or the $\beta_{B}$-subunit to form inhibin-B (Ying 1988); inhibin-B is also the form secreted by the testis (Anawalt et al. 1996,
Woodruff et al. 1996). Inhibin $\alpha$-subunit mRNA is found in the rat pituitary in low concentration using solution hybridization methods (Bilezikjian et al. 1996) but was undetectable by northern hybridization in monkey pituitary RNA (Attardi et al. 1992). However, an antiserum to porcine $\alpha$-inhibin identified immunoreactive inhibin throughout the pars distalis of the crab-eating and rhesus monkey pituitary (Schlatt et al. 1991) suggesting that the pituitary may also produce inhibin in the male primate and rat.

Like other members of the transforming growth factor (TGF)- $\beta$ superfamily of proteins, activins and inhibins initiate their actions by binding to a complex of transmembrane serine and threonine kinase receptors. Activin binds an activin type-II receptor, and then an activin type-I receptor is recruited into the complex. Once activated, the type-I receptor kinase stimulates a novel family of proteins called Smads (Attisano \& Wrana 1998). Activin signaling is relayed through Smad2 and Smad3. Once activated by phosphorylation, Smad2 or Smad3 associate with the common Smad4, and the dimer migrates to the nucleus to bind specific promoters, known as Smad-binding elements (SBEs). SBEs are ubiquitous and not sufficient for activin activation, and signaling specificity for gonadotrophs presumably requires cell-specific transcriptional cofactors and co-activators (Massague \& Chen 2000).

Inhibins are thought to exert their antagonistic effects by competing with activins for binding to the activin receptor II presumably through the $\beta$-subunit they share with activin (Xu et al. 1995). Inhibin fails, however, to stimulate phosphorylation of the type-I receptor. While inhibin at low concentrations blocks activin signaling, it binds recombinant activin receptor II with only $10 \%$ of the 
affinity of activin (Mathews \& Vale 1991). It is now known that betaglycan functions as an inhibin co-receptor to increase its binding affinity for activin receptor II (Gray et al. 2002). In this way, the endocrine hormone inhibin is present in sufficient concentration to block the effect of locally produced activins.

Follistatin, a cysteine-rich glycosylated monomeric protein that is structurally unrelated to inhibin and activin, is co-expressed with activin in essentially all tissues (Kawakami et al. 2001), and functions as a high-affinity activinbinding protein (Nakamura et al. 1990). There are two forms of follistatin mRNA generated by alternative splicing which code for follistatin-315 and its carboxy-truncated form, follistatin-288. Recombinant human follistatin-288 has 8- to 10-fold greater FSH suppressing ability than follistatin-315 (Inouye et al. 1991), but is a minor form representing $<5-10 \%$ of follistatin-315 mRNA (Kawakami et al. 2001). With a short biological half-life (Kogure et al. 1996) follistatin is able to rapidly modulate activin binding to its receptors (Phillips \& de Kretser 1998).

Follistatin appears to be expressed by all pituitary cells (Lee et al. 1993). Attention has focused on gonadotrophs and folliculostellate cells, however, since there is evidence that the latter cell type serves a paracrine function in the pituitary. Folliculostellate cells account for about $10 \%$ of the cells in the rat anterior pituitary. These star-shaped cells encircle well-defined cavities, and extend cytoplasmic processes (Soji et al. 1997) that connect with other folliculostellate cells by gap-junction channels (Fauquier et al. 2001) and communicate by calcium waves (Inoue et al. 1999).

\section{Paracrine regulation of the gonadotropin subunit and GnRH-receptor genes}

Many studies have shown that activin is the pituitaryderived factor that selectively stimulates $\mathrm{FSH}$ synthesis. Activin stimulates FSH secretion and FSH- $\beta$ mRNA levels in vitro and in vivo (Ling et al. 1986, Vale et al. 1986, Weiss et al. 1993), and FSH- $\beta$ mRNA and circulating FSH are reduced in mice deficient in the activin receptor (Matzuk et al. 1995, Kumar et al. 2003). When rat pituitary cell cultures are prolonged in the absence of $\mathrm{GnRH}$, $\mathrm{FSH}-\beta$ mRNA expression is maintained, and a substantial amount of FSH but little LH is produced (Farnworth 1995). In this model, blocking activin receptors with inhibin, or adding follistatin to bind activin, reduces FSH- $\beta$ mRNA levels and FSH secretion (Ying 1988). Furthermore, immunoneutralization with an antibody to activin-B inhibited $\mathrm{FSH}$ release and reduced $\mathrm{FSH}-\beta$ gene expression (Corrigan et al. 1991).

Activin increases FSH- $\beta$ expression at the level of transcription since nuclear transcripts in rat pituitary cells are increased by activin, and the increase is blocked by actinomycin-D (Weiss et al. 1995). Activin stimulates the ovine $\mathrm{FSH}-\beta$ proximal promoter in pituitary cells from mice expressing the o-FSH- $\beta$ transgene (Huang et al. 2001) and augments up-regulation by GnRH (Pernasetti et al. 2001). Activin signaling to the FSH- $\beta$ promoter is through Smad-3 and is augmented by Smad-4, and gonadotroph-specific expression of FSH- $\beta$ is partly explained by Pitx2, a factor required for pituitary development, that binds the rat $\mathrm{FSH}-\beta$ promoter and stimulates basal and activin-stimulated transcription (Suszko et al. 2003). Activin also increases $\mathrm{FSH}-\beta$ mRNA levels by prolonging the half-life of FSH- $\beta$ mRNA transcripts (Carroll et al. 1991, Attardi \& Winters 1993).

The glycoprotein $\alpha$-subunit gene is expressed by gonadotrophs and thyrotrophs, and during fetal development is one of the first indicators of pituitary cell differentiation (Rosenfeld et al. 2000). Rat anterior pituitary cells in culture produce $\alpha$-subunit in the absence of $\mathrm{GnRH}$, and $\alpha$ subunit is found in the circulation in men with $\mathrm{GnRH}$ deficiency treated with thyroxine to suppress thyroid-stimulating hormone (TSH). Multiple elements in the promoter region contribute to $\alpha$-subunit expression including tandem cAMP response elements in the human gene, a consensus GATA site and a steroidogenic factor-1 (SF-1) site (Barnhart \& Mellon 1994, Maurer et al. 1999). The pituitary glycoprotein hormone basal element (PBGE) is important in basal transcription through interaction with LIM homeodomain proteins (Heckert et al. 1996), but how basal expression is maintained at a high level is not well understood. There is little effect of activin on $\alpha$-subunit expression (Attardi et al. 1989). Pituitary adenylate cyclase-activating polypeptide (PACAP) stimulates $\alpha$-subunit transcription by activating a G-protein receptor that couples primarily to cAMP/protein kinase A (PKA) (Tsujii et al. 1995, Fowkes et al. 2001). PACAP is expressed in the hypothalamus (Masuo et al. 1994) and the embryonic pituitary (Skoglosa et al. 1999), but in the adult pituitary is present in low levels (J Moore, unpublished observations), and its role as a paracrine regulator of gonadotrophs remains to be clarified.

The number of GnRH-receptors is an important determinant of gonadotropin secretion. Activin stimulates $\mathrm{GnRH}$-receptor synthesis (Braden \& Conn 1992) and increases the number of gonadotrophs that are $\mathrm{GnRH}$ responsive (Childs \& Unabia 1997), and up-regulation is blocked by inhibin (Braden et al. 1990, Winters et al. 1996) or follistatin (Fernandez-Vazquez et al. 1996, Duval et al. 1999). There is an activin-response element within $-387 /-308$ of mouse GnRH-R promoter (Norwitz et al. 2002a), and electrophoretic mobility shift assay experiments using $\alpha \mathrm{T} 3-1$ nuclear extract or SMAD, Jun, and Fos proteins demonstrated direct binding of activator protein complex-1 (AP-1) (Fos/Jun) protein complexes to (327/(322, and SMAD proteins to (329/(328 (Norwitz et al. $2002 b$ ). While activin was found to promote $\mathrm{GnRH}$ mediated transcriptional activation of the mouse GnRH-R gene (Norwitz et al. 2002a), no promoter activation was found with activin alone, suggesting that increased receptor synthesis in activin-treated pituitary cells in the absence of $\mathrm{GnRH}$ could represent a post-transcriptional effect. PACAP renders gonadotrophs more responsive 
to $\mathrm{GnRH}$ (Tsujii et al. 1994). PACAP stimulates the $\mathrm{GnRH}$ promoter (Pincas et al. 2001) and may regulate the expression of the GnRH-R gene.

\section{Paracrine control of gonadotropins and pubertal maturation in the male rat}

The pituitary gonadotropins are differentially regulated during maturation in the male rat. Between postnatal days 20 and 30, serum FSH rises to levels that exceed those of adult rats while there is little or no change in LH concentrations (Swerdloff et al. 1971, Payne et al. 1977, Ketelslegers et al. 1978, Merry \& Holehan 1981). Figure 1 demonstrates that this disparity is due to the differential expression of the gonadotropin subunit genes, and that $\mathrm{GnRH}$-receptor mRNA increases in parallel with FSH- $\beta$ (Moore et al. 2003, Zapatero-Caballero et al. 2003). While the mechanism controlling the selective rise of these mRNAs has not yet been thoroughly elucidated, up-regulation was blocked by a GnRH antagonist (Zapatero-Caballero et al. 2003), and both genes are stimulated by activin.

A role for inhibin in the control of FSH during postnatal development in the male rat was proposed from the rise in circulating FSH that followed immuno-neutralization with an $\alpha$-inhibin antiserum in juvenile rats that was lost after puberty (Culler \& Negro-Vilar 1988, Rivier et al. 1988). Immunoreactive inhibin was subsequently reported to decline coincident with the rise in FSH (Ackland \& Schwartz 1991). Although the inhibin immunoassay used did not discriminate between the bioactive inhibin $\alpha-\beta$ dimer and the uncombined inhibin- $\alpha$ subunit that circulates in excess, results with specific two-site ELISAs for inhibin-B (Woodruff et al. 1996, Sharpe et al. 1999) tend to confirm those findings.

Other factor(s) may contribute to the differential regulation of the gonadotropins during the juvenile period. We studied pituitary follistatin mRNA expression (Moore et al. 2003) and found no significant change in the mRNA species encoding the larger and more abundant follistatin315 peptide between ages 20 and 30 days. By contrast, the mRNA encoding the more potent follistatin-288 is significantly reduced from day 20 to 30 . This reduction is

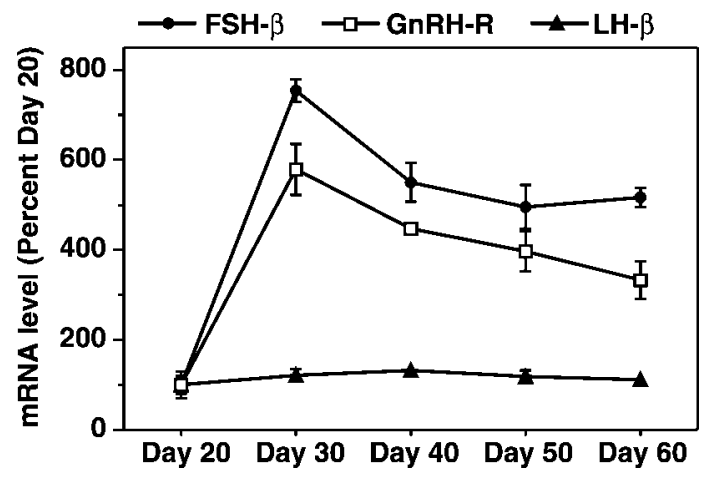

Figure 1 Developmental changes in mRNA expression in male rats. Data from Moore et al. 2003. reciprocal to the increased level of expression of $\mathrm{FSH}-\beta$ mRNA, and is followed by an increase in follistatin-288 mRNA that is coincident with the decline in $\mathrm{FSH} \beta$ mRNA expression to adult levels. Therefore, changes in follistatin expression may be responsible for increases and decreases in pituitary activin tone, and synergize with inhibin to influence gonadotropin subunit and $\mathrm{GnRH}$-receptor gene expression during sexual maturation.

\section{Paracrine regulation of gonadotrophs in male primates}

The activin-inhibin-follistatin system also regulates gonadotrophs in primates. Activin stimulates FSH secretion and FSH- $\beta$ mRNA in pituitary cell cultures from human abortuses and adult male rhesus monkeys (Blumenfeld \& Ritter 2001, Kawakami et al. 2002), and up-regulation of $\mathrm{GnRH}$-receptors by activin is inferred from the rise in $\mathrm{GnRH}$-stimulated FSH and $\mathrm{LH}$ secretion that followed rhactivin-A infusion in cynomolgus monkeys (McLachlan et al. 1989). FSH secretion by human and non-human primate pituitary cultures is suppressed by inhibin (Fingscheidt et al. 1998, Blumenfeld \& Ritter 2001). But unlike in rats, $\mathrm{FSH}-\beta$ gene expression and $\mathrm{FSH}$ secretion is not sustained in monkey pituitary cultures when $\mathrm{GnRH}$ is absent, in part because of follistatin production by proliferating folliculostellate cells (Kawakami et al. 2002).

FSH secretion in vivo is also more dependent on $\mathrm{GnRH}$ in male primates than in rats. Prepubertal boys, in whom $\mathrm{GnRH}$ is secreted at low levels, and men with a complete form of congenital hypogonadotropic hypogonadism have low plasma levels of both $\mathrm{FSH}$ and $\mathrm{LH}$. Furthermore, the level of expression of the mRNAs for both FSH- $\beta$ and $\mathrm{LH}-\beta$ is very low in prepubertal monkeys (S Winters and T Plant, unpublished observations). Circulating levels of FSH are low in prepubertal boys with bilateral cryptorchidism but are increased in adults (Christiansen et al. 2002). $\mathrm{GnRH}$ antagonists reduce circulating FSH as well as $\mathrm{LH}$ in normal adult men, although suppression of LH may be proportionately greater (Herbst et al. 2002). The anencephalic fetus, which lacks a hypothalamus, produces glycoprotein $\alpha$-subunit but little or no FSH- $\beta$ or LH- $\beta$ subunits (Hagen \& McNeilly 1975). Finally, the switch from a positive to a negative correlation between circulating levels of inhibin-B and FSH during human puberty (Andersson et al. 1998), and the suppression of FSH- $\beta$ mRNA when orchidectomized adult monkeys are treated with inhibin (Majumdar et al. 1995) imply that the activin/inhibin system for the paracrine regulation of $\mathrm{FSH}$ in primates becomes operational as $\mathrm{GnRH}$ increases.

There is evidence that pituitary autocrine/paracrine factors may explain the markedly greater post-orchidectomy rise in $\mathrm{FSH}$ that occurs in male primates when compared with rats. Whereas plasma FSH levels increase 1- to 4-fold following orchidectomy in rats (Rodi et al. 1990), FSH levels in long-term-castrated rhesus monkeys (Attardi et al. 1992) and orchidectomized human males are 
50- to 100-fold increased. These increases are paralleled by proportionate increments in FSH- $\beta$ mRNA concentrations: in rats, orchidectomy increases FSH- $\beta$ mRNA levels 2 - to 4 -fold whereas in the monkey, pituitary FSH- $\beta$ mRNA is increased 20- to 40 -fold by castration (Fig. 2). Species differences in pituitary follisatin expression contribute to these differing $\mathrm{FSH}$ responses. In rats, pituitary follistatin expression gradually increases over 2 weeks following orchidectomy to peak levels up to 25-fold higher than those of intact male rats (Kaiser \& Chin 1993). FSH- $\beta$ mRNA levels rise following orchidectomy in rats to peak increments of 2- to 4-fold at 7-10 days, which in many studies is followed by a decline to values that are similar to, or only slightly higher than intact controls by day 28. Although the castration-associated rises in FSH- $\beta$ (Rodin et al. 1989) and follistatin mRNAs (Dalkin et al. 1998) are each $\mathrm{GnRH}$ dependent, the more gradual rise in follistatin expression has not been explained. Overall, the time course of the changes in follistatin and FSH- $\beta$ mRNAs suggest that follistatin acts to restrain $\mathrm{FSH}-\beta$ gene expression subsequent to orchidectomy in male rats.

In primates, by contrast, the results in Fig. 3 reveal that follistatin mRNA levels are unaffected by bilateral orchidectomy (Winters et al. 2001), and it is therefore tempting to propose that the large 50-fold increase in FSH- $\beta$ mRNA levels and FSH secretion occur partly because there is no rise in follistatin to restrain $\mathrm{FSH}-\beta$ gene expression. Insight into this hypothesis derives from experiments in vitro in which GnRH was shown to increase follistatin expression in pituitary cell cultures from rats but not from monkeys (Kawakami et al. 2002). This finding could be explained
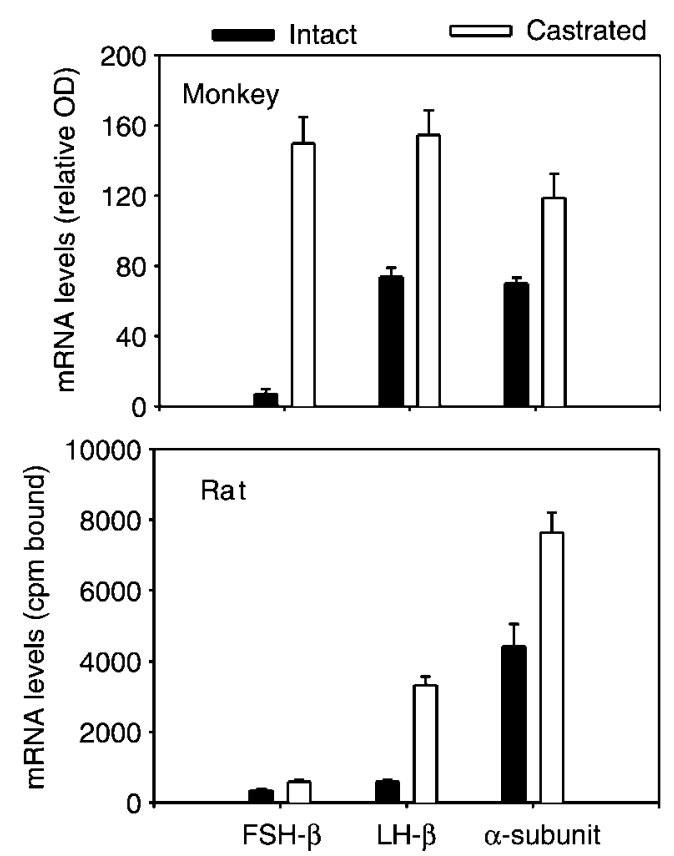

Figure 2 A comparison of the effects of orchidectomy on gonadotropin subunit mRBA levels in adult male monkeys and rats. From Winters et al. 2001.

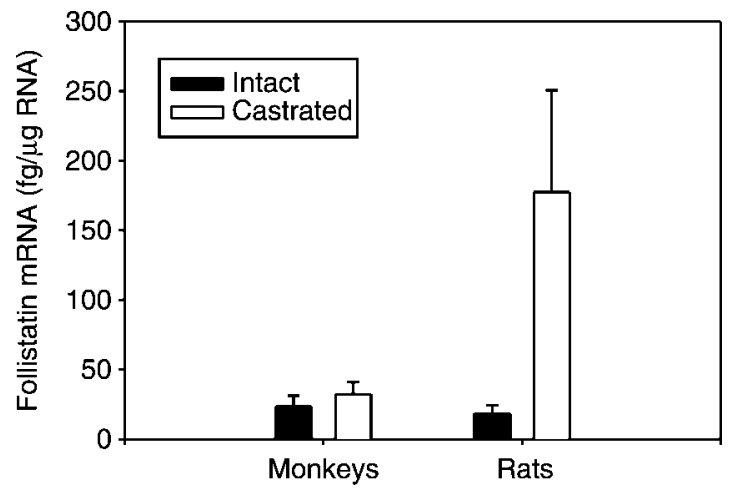

Figure 3 Pituitary follistatin mRNA concentrations in intact and orchidectomized adult male monkeys and rats. Data from Winters et al. 2001.

by species differences in the pituitary cells that express follistatin, or by differences in $\mathrm{GnRH}$ signaling pathways that activate follistatin expression in gonadotrophs.

$\mathrm{GnRH}$ pulse frequency is believed to differentially regulate $\mathrm{LH}$ and $\mathrm{FSH}$ production. Experiments in ovariectomized GnRH-deficient monkeys first demonstrated that $\mathrm{GnRH}$ at slow frequencies favors $\mathrm{FSH}$ over $\mathrm{LH}$ secretion (Wildt et al. 1981). Subsequently, rapid-frequency $\mathrm{GnRH}$ pulses administered to ovariectomized ewes in which $\mathrm{GnRH}$ was suppressed by progesterone treatment were found to increase $\alpha$-subunit and LH- $\beta$ more than FSH- $\beta$ mRNA (Leung et al. 1987). Experiments in male rats (Dalkin et al. 1989, Kirk et al. 1994) and in pituitary cell cultures from orchidectomized testosteronereplaced male rats (Besecke et al. 1996) have shown that rapid $\mathrm{GnRH}$ pulse frequencies (e.g. every 15-30 min) favor LH- $\beta$ over FSH- $\beta$ gene expression. GnRH applied continuously (Attardi et al. 1989) or as rapid-frequency pulses (Besecke et al. 1996, Dalkin et al. 1999) up-regulates follistatin mRNA in this species. The consequence is a presumed blockade by follistatin of activin-stimulated FSH- $\beta$ gene expression.

Since follistatin in the primate pituitary does not appear to be increased by $\mathrm{GnRH}$, how GnRH pulse frequency might regulate $\mathrm{FSH}$ and $\mathrm{LH}$ production differentially in primates is less clear. In orchidectomized adult male monkeys rendered gonadotropin deficient by arcuate lesions, GnRH replacement at 1 pulse per hour produced higher $\mathrm{LH}$ but similar FSH levels to $\mathrm{GnRH}$ every $3 \mathrm{~h}$, suggesting that $\mathrm{GnRH}$ pulse frequency is an important determinant of $\mathrm{LH}$ but not of FSH secretion in male primates (Plant \& Dubey 1984). In men with congenital hypogonadotropic hypogonadism who were treated long-term with pulsatile GnRH, increasing the frequency of $\mathrm{GnRH}$ stimulation from every $2 \mathrm{~h}$ to every 30 min for 7 days increased serum LH levels 3fold, and FSH levels rose by 50\% (Spratt et al. 1987) and in a similar population of men, increasing the $\mathrm{GnRH}$ pulse frequency from every $1.5 \mathrm{~h}$ to every $0.5 \mathrm{~h}$ suppressed plasma FSH but plasma LH levels were unchanged (Gross et al. 1986). Gonadotrophs are known to secrete less FSH than $\mathrm{LH}$ in response to stimulation by $\mathrm{GnRH}$, and in each 

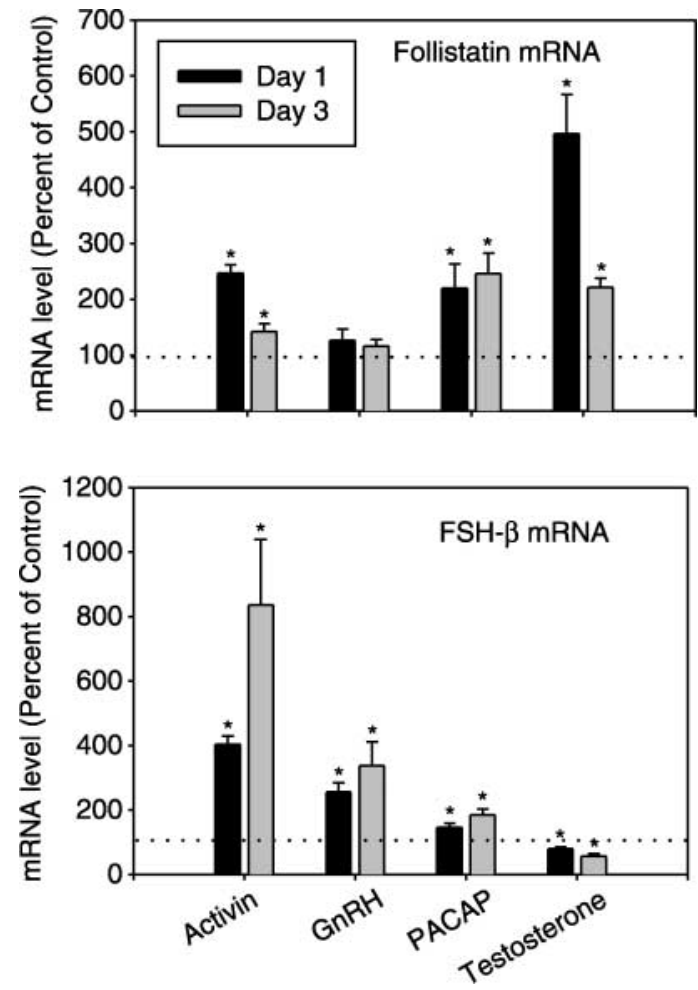

Figure 4 Follistatin and FSH- $\beta$ mRNA levels in primary pituitary cell cultures from adult male rhesus monkeys treated with test substances for 1 or 3 days. From Kawakami et al. 2002. ${ }^{*} P<0.05$ vs vehicle treated cultures, adjusted to $100 \%$.

of the studies in men, the interpretation of the results is further complicated by changes in testosterone, estradiol and inhibin-B as a consequence of increased $\mathrm{GnRH}$.

Species differences in pituitary follistatin may also explain why FSH regulation by androgens differs in primates and rats. When androgens are administered to rats,
FSH secretion decreases because $\mathrm{GnRH}$ and $\mathrm{GnRH}-\mathrm{R}$ are suppressed, however LH is suppressed more effectively in castrated rats than is FSH (Swerdloff et al. 1973). While there are several potential explanations for this difference in feedback control, testosterone was subsequently found to increase FSH secretion directly (Mittler 1974) by stimulating FSH- $\beta$ mRNA (Gharib et al. 1990), an effect which tends to offset feedback inhibition of $\mathrm{GnRH}$ and its receptor. The rise in $\mathrm{FSH}-\beta$ during androgen treatment in the absence of $\mathrm{GnRH}$ is partly due to suppression of follistatin (Bilezikjian et al. 1996) which allows activin to upregulate the FSH- $\beta$ gene. Testosterone was also shown recently to increase FSH- $\beta$ mRNA primary transcripts in rat pituitary cell cultures treated with follistatin (Burger et al. 2004) implying a direct effect on rat FSH transcription, as well as to activate the ovine $\mathrm{FSH}-\beta$ promoter in $\mathrm{L} \beta \mathrm{T}-2$ cells (Spady et al. 2004). On the other hand in monkeys (Khurshid et al. 1991) and men, the combination of testosterone and a $\mathrm{GnRH}$ antagonist reduced serum FSH levels more effectively than a GnRH antagonist alone, and testosterone enanthate suppressed circulating FSH levels in untreated GnRH-deficient men (Winters 1994). Moreover, unlike in rats, follistatin expression in primate pituitary cell cultures is stimulated by testosterone, and FSH- $\beta$ mRNA is suppressed (Kawakami et al. 2002) (Fig. 4). Androgens decreased human FSH- $\beta$ mRNA levels in pituitary cells from mice expressing this human transgene (Kumar \& Low 1995) suggesting that species-specific factors in the pituitary cellular environment rather than motifs in the hFSH- $\beta$ promoter are responsible for the differences in $\mathrm{FSH}$ regulation by testosterone in rodents and primates.

Gonadal steroids also affect GnRH-stimulated $\mathrm{LH}$ and FSH secretion and gonadotropin subunit gene expression differently in male primates and rats. Testosterone suppresses, and estradiol increases $\mathrm{GnRH}$-stimulated $\mathrm{LH}$ and

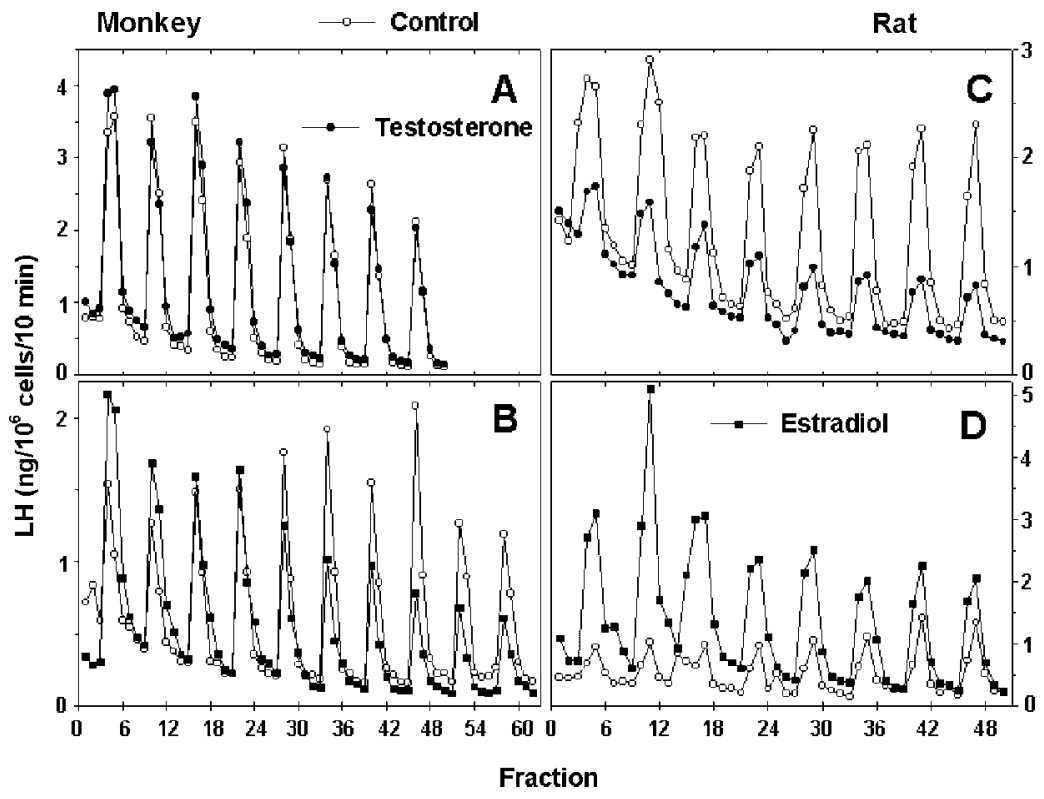

Reproduction (2004) 128 13-23
Figure 5 Effects of testosterone or estradiol on GnRH-stimulated LH secretion by cultured pituitary cells from adult male monkeys ( $\mathrm{A}$ and $\mathrm{B}$ ) or rats $(\mathrm{C}$ and D). Cells were treated with $10 \mathrm{nM}$ testosterone ( $\mathrm{A}$ and $\mathrm{C}$ ) or $0.1 \mathrm{nM}$ estradiol ( $\mathrm{B}$ and $\mathrm{D}$ ) beginning $48 \mathrm{~h}$ before the perifusion. Pulses of $10 \mathrm{nM}$ GnRH were administered hourly. From Kawakami \& Winters 1999. 
FSH secretion by pituitary cells from rats (Labrie et al. 1978) whereas in monkey pituitary cells, we (Kawakami \& Winters 1999) found no significant effect of testosterone or dihydrotestosterone, while for estradiol, an initial period of enhancement was followed by significant supression of $\mathrm{GnRH}$-stimulated gonadotropin release (Fig. 5). These differences are partly through $\mathrm{GnRH}$-receptors that in the rat are increased by estradiol (Emons et al. 1988) and downregulated by androgens (Giguere et al. 1981). While less is known about GnRH-receptors in the male primate, pituitary mRNA levels are decreased by estradiol while androgens appear to be without effect (Kawakami \& Winters 1999). $\alpha$-Subunit mRNA levels are also directly suppressed by androgens in pituitary cells from rats but not primates. Androgen receptors are expressed in primate gonadotrophs, and appear to traffic normally (Okada et al. 2003), and the resistance of primate gonadotrophs to androgens remains unexplained.

Finally, inhibin-B appears to play a greater role in the regulation of $\mathrm{FSH}-\beta$ gene expression in adult monkeys than in rats. Specifically, while immunoneutralization of circulating inhibin failed to increase FSH secretion in adult rats (Culler \& Negro-Vilar 1988, Rivier et al. 1988), this experimental approach increased FSH in adult monkeys (Medhamurthy et al. 1991). Interestingly, however, circulating inhibin levels in rats and monkeys tend to overlap (Sharpe et al. 1999). Perhaps because the current two-site inhibin-B assays utilize antisera against the human inhibin subunits, and there are large-molecular-weight forms of circulating inhibin-B of uncertain bioactivity, at least in primates (Robertson et al. 1996, Winters \& Plant 1999), immunoassay detection and specificity may differ in primates and rats. If so, the greater rise in FSH following castration or immunoneutralization of inhibin in male primates could reflect higher circulating levels of bioactive inhibin-B.

\section{References}

Ackland JF \& Schwartz NB 1991 Changes in serum immunoreactive inhibin and follicle-stimulating hormone during gonadal development in male and female rats. Biology of Reproduction 45 295-300.

Anawalt BD, Bebb RA, Matsumoto AM, Groome NP, Illingworth PJ, McNeilly AS \& Bremner WJ 1996 Serum inhibin B levels reflect Sertoli cell function in normal men and men with testicular dysfunction. Journal of Clinical Endocrinology and Metabolism 81 $3341-3345$

Andersson AM, Toppari J, Haavisto AM, Petersen JH, Simell T, Simell O \& Skakkebaek NE 1998 Longitudinal reproductive hormone profiles in infants: peak of inhibin B levels in infant boys exceeds levels in adult men. Journal of Clinical Endocrinology and Metabolism 83 675-681.

Attardi B \& Winters SJ 1993 Decay of follicle-stimulating hormonebeta messenger RNA in the presence of transcriptional inhibitors and/or inhibin, activin, or follistatin. Molecular Endocrinology 7 $668-680$.

Attardi B, Keeping HS, Winters SJ, Kotsuji F \& Troen P 1989 Effect of inhibin from primate Sertoli cells and $\mathrm{GnRH}$ on gonadotropin subunit mRNA in rat pituitary cell cultures. Molecular Endocrinology 3 1236-1242.
Attardi B, Marshall GR, Zorub DS, Winters SJ, Miklos J \& Plant TM 1992 Effects of orchidectomy on gonadotropin and inhibin subunit messenger ribonucleic acids in the pituitary of the rhesus monkey (Macaca mulatta). Endocrinology 130 1238-1244.

Attisano L \& Wrana JL 1998 Mads and Smads in TGF beta signalling. Current Opinion in Cell Biology 10 188-194.

Barnhart KM \& Mellon PL 1994 The orphan nuclear receptor, steroidogenic factor-1, regulates the glycoprotein hormone alpha-subunit gene in pituitary gonadotropes. Molecular Endocrinology $\mathbf{8}$ 878-885.

Bauer-Dantoin AC, Knox KL, Schwartz NB \& Levine JE 1993 Estrous cycle stage-dependent effects of neuropeptide-Y on luteinizing hormone (LH)-releasing hormone-stimulated $\mathrm{LH}$ and follicle-stimulating hormone secretion from anterior pituitary fragments in vitro. Endocrinology 133 2413-2417.

Besecke LM, Guendner MJ, Schneyer AL, Bauer DA, Jameson JL \& Weiss J 1996 Gonadotropin-releasing hormone regulates folliclestimulating hormone-beta gene expression through an activin/follistatin autocrine or paracrine loop. Endocrinology 137 3667-3673.

Bilezikjian LM, Corrigan AZ, Blount AL \& Vale WW 1996 Pituitary follistatin and inhibin subunit messenger ribonucleic acid levels are differentially regulated by local and hormonal factors. Endocrinology $1374277-4284$.

Blumenfeld Z \& Ritter M 2001 Inhibin, activin, and follistatin in human fetal pituitary and gonadal physiology. Annals of the New York Academy of Sciences 943 34-48.

Braden TD \& Conn PM 1992 Activin-A stimulates the synthesis of gonadotropin-releasing hormone receptors. Endocrinology 130 2101-2105.

Braden TD, Farnworth PG, Burger HG \& Conn PM 1990 Regulation of the synthetic rate of gonadotropin-releasing hormone receptors in rat pituitary cell cultures by inhibin. Endocrinology 127 $2387-2392$.

Burger LL, Haisenleder DJ, Aylor KW, Dalkin AC, Prendergast KA \& Marshall JC 2004 Regulation of luteinizing hormone-beta and follicle-stimulating hormone (FSH)-beta gene transcription by androgens: testosterone directly stimulates FSH-beta transcription independent from its role on follistatin gene expression. Endocrinology $14571-78$.

Carroll RS, Corrigan AZ, Vale W \& Chin WW 1991 Activin stabilizes follicle-stimulating hormone-beta messenger ribonucleic acid levels. Endocrinology 129 1721-1726.

Ceccatelli S, Hulting AL, Zhang X, Gustafsson L, Villar M \& Hokfelt T 1993 Nitric oxide synthase in the rat anterior pituitary gland and the role of nitric oxide in regulation of luteinizing hormone secretion. PNAS $9011292-11296$.

Chen ZP, Kratzmeier M, Levy A, McArdle CA, Poch A, Day A, Mukhopadhyay AK \& Lightman SL 1995 Evidence for a role of pituitary ATP receptors in the regulation of pituitary function. PNAS 92 5219-5223.

Cheng KW \& Leung PC 2000 The expression, regulation and signal transduction pathways of the mammalian gonadotropin-releasing hormone receptor. Canadian Journal of Physiology and Pharmacology 78 1029-1052.

Childs G \& Unabia G 1997 Cytochemical studies of the effects of activin on gonadotropin-releasing hormone $(\mathrm{GnRH})$ binding by pituitary gonadotropes and growth hormone cells. Journal of Histochemistry and Cytochemistry 45 1603-1610.

Christiansen P, Andersson AM, Skakkebaek NE \& Juul A 2002 Serum inhibin B, FSH, LH and testosterone levels before and after human chorionic gonadotropin stimulation in prepubertal boys with cryptorchidism. European Journal of Endocrinology 147 95-101.

Corrigan AZ, Bilezikjian LM, Carroll RS, Bald LN, Schmelzer CH, Fendly BM, Mason AJ, Chin WW, Schwall RH \& Vale W 1991 Evidence for an autocrine role of activin $B$ within rat anterior pituitary cultures. Endocrinology 128 1682-1684. 
Culler MD \& Negro-Vilar A 1986 Evidence that pulsatile follicle-stimulating hormone secretion is independent of endogenous luteinizing hormone-releasing hormone. Endocrinology 118 609-612.

Culler MD \& Negro-Vilar A 1988 Passive immunoneutralization of endogenous inhibin: sex-related differences in the role of inhibin during development. Molecular and Cellular Endocrinology $\mathbf{5 8}$ 263-273.

Culler MD \& Paschall CS 1991 Pituitary adenylate cyclase-activating polypeptide (PACAP) potentiates the gonadotropin-releasing activity of luteinizing hormone-releasing hormone. Endocrinology 129 2260-2262.

Dalkin AC, Haisenleder DJ, Gilrain JT, Aylor K, Yasin M \& Marshall JC 1998 Regulation of pituitary follistatin and inhibin/activin subunit messenger ribonucleic acids (mRNAs) in male and female rats: evidence for inhibin regulation of follistatin mRNA in females. Endocrinology 139 2818-2823.

Dalkin AC, Haisenleder DJ, Ortolano GA, Ellis TR \& Marshall JC 1989 The frequency of gonadotropin-releasing-hormone stimulation differentially regulates gonadotropin subunit messenger ribonucleic acid expression. Endocrinology 125 917-924.

Dalkin AC, Haisenleder DJ, Gilrain JT, Aylor K, Yasin M \& Marshall JC 1999 Gonadotropin-releasing hormone regulation of gonadotropin subunit gene expression in female rats: actions on folliclestimulating hormone beta messenger ribonucleic acid (mRNA) involve differential expression of pituitary activin (beta-B) and follistatin mRNAs. Endocrinology 140 903-908.

Debeljuk L \& Bartke A 1994 Immunoreactive substance P and neurokinin $\mathrm{A}$ in the hypothalamus and anterior pituitary gland of Siberian and Syrian hamsters and of rats. Journal of Reproduction and Fertility 101 427-434.

De Jong FH 1979 Inhibin - fact or artifact. Molecular and Cellular Endocrinology 13 1-10.

De Jong FH 1988 Inhibin. Physiological Reviews 68 555-607.

DePaolo LV, Bicsak TA, Erickson GF, Shimasaki S \& Ling N 1991 Follistatin and activin: a potential intrinsic regulatory system within diverse tissues [published erratum appears in Proceedings of the Society for Experimental Biology and Medicine 1992200 447; Review, 117 refs]. Experimental Biology and Medicine 198 500-512.

Duval DL, Ellsworth BS \& Clay CM 1999 Is gonadotrope expression of the gonadotropin releasing hormone receptor gene mediated by autocrine/paracrine stimulation of an activin response element? Endocrinology 140 1949-1952.

Emons G, Hoffmann HG, Brack C, Ortmann O, Sturm R, Ball P \& Knuppen R 1988 Modulation of gonadotropin-releasing hormone receptor concentration in cultured female rat pituitary cells by estradiol treatment. Journal of Steroid Biochemistry 31 751-756.

Farnworth PG 1995 Gonadotrophin secretion revisited. How many ways can FSH leave a gonadotroph? Journal of Endocrinology $\mathbf{1 4 5}$ 387-395.

Fauquier T, Guerineau NC, McKinney RA, Bauer K \& Mollard P 2001 Folliculostellate cell network: a route for long-distance communication in the anterior pituitary. PNAS 98 8891-8896.

Fernandez-Vazquez G, Kaiser UB, Albarracin CT \& Chin WW 1996 Transcriptional activation of the gonadotropin-releasing hormone receptor gene by activin A. Molecular Endocrinology 10 356-366.

Fingscheidt U, Weinbauer GF, Fehm HL \& Nieschlag E 1998 Regulation of gonadotrophin secretion by inhibin, testosterone and gonadotrophin-releasing hormone in pituitary cell cultures of male monkeys. Journal of Endocrinology 159 103-110.

Fowkes RC, Burch J \& Burrin JM 2001 Stimulation of extracellular signal-regulated kinase by pituitary adenylate cyclase-activating polypeptide in alpha T3-1 gonadotrophs. Journal of Endocrinology 171 R5-R10.

Gharib SD, Leung PC, Carroll RS \& Chin WW 1990 Androgens positively regulate follicle-stimulating hormone beta-subunit mRNA levels in rat pituitary cells. Molecular Endocrinology 4 1620-1626.
Giguere V, Lefebvre FA \& Labrie F 1981 Androgens decrease LHRH binding sites in rat anterior pituitary cells in culture. Endocrinology $108350-352$.

Gray PC, Bilezikjian LM \& Vale W 2002 Antagonism of activin by inhibin and inhibin receptors: a functional role for betaglycan. Molecular and Cellular Endocrinology 188 254-260.

Gross KM, Matsumoto AM, Berger RE \& Bremner WJ 1986 Increased frequency of pulsatile luteinizing hormone-releasing hormone administration selectively decreases follicle-stimulating hormone levels in men with idiopathic azoospermia. Fertility and Sterility $45392-396$.

Grotjan HE Jr, Leveque NW, Berkowitz AS \& Keel BA 1984 Quantitation of LH subunits released by rat anterior pituitary cells in primary culture. Molecular and Cellular Endocrinology 35 121-129.

Hagen C \& McNeilly AS 1975 The gonadotropic hormones and their subunits in human maternal and fetal circulation at delivery. American Journal of Obstetrics and Gynecology 121 926-930.

Heckert LL, Schultz K \& Nilson JH 1996 The cAMP response elements of the alpha subunit gene bind similar proteins in trophoblasts and gonadotropes but have distinct functional sequence requirements. Journal of Biological Chemistry 271 31650-31656.

Herbst KL, Anawalt BD, Amory JK \& Bremner WJ 2002 Acyline: the first study in humans of a potent, new gonadotropin-releasing hormone antagonist. Journal of Clinical Endocrinology and Metabolism 87 3215-3220.

Heritier AG \& Dubois PM 1993 Influence of thyroliberin on the rat pituitary cell type differentiation: an in vitro study. Endocrinology $132634-639$.

Heritier AG \& Dubois PM 1994 Re-evaluation of gonadotropinreleasing hormone $(\mathrm{GnRH})$ action on pituitary cell differentiation with special regard to its effect on $\mathrm{LH}$ and TSH cell types. Journal of Neuroendocrinology 6 33-37.

Huang HJ, Sebastian J, Strahl BD, Wu JC \& Miller WL 2001 Transcriptional regulation of the ovine follicle-stimulating hormonebeta gene by activin and gonadotropin-releasing hormone $(\mathrm{GnRH})$ : involvement of two proximal activator protein-1 sites for $\mathrm{GnRH}$ stimulation. Endocrinology 142 2267-2274.

Inoue K, Couch EF, Takano K \& Ogawa S 1999 The structure and function of folliculo-stellate cells in the anterior pituitary gland. Archives of Histology and Cytology 62 205-218.

Inouye S, Guo Y, DePaolo L, Shimonaka M, Ling N \& Shimasaki S 1991 Recombinant expression of human follistatin with 315 and 288 amino acids: chemical and biological comparison with native porcine follistatin. Endocrinology $129815-822$.

Itoh S, Itoh F, Goumans MJ \& Ten Dijke P 2000 Signaling of transforming growth factor-beta family members through Smad proteins. European Journal of Biochemistry 267 6954-6967.

Kaiser UB \& Chin WW 1993 Regulation of follistatin messenger ribonucleic acid levels in the rat pituitary. Journal of Clinical Investigation 91 2523-2531.

Kakar SS, Malik MT \& Winters SJ 2002 Gonadotropin-releasing hormone receptor: cloning, expression and transcriptional regulation. Progress in Brain Research 141 129-147.

Kakar SS, Winters SJ, Zacharias W, Miller DM \& Flynn S 2003 Identification of distinct gene expression profiles associated with treatment of LbetaT2 cells with gonadotropin-releasing hormone agonist using microarray analysis. Gene 308 67-77.

Kawakami S \& Winters SJ 1999 Regulation of lutenizing hormone secretion and subunit messenger ribonucleic acid expression by gonadal steroids in perifused pituitary cells from male monkeys and rats. Endocrinology 140 3587-3593.

Kawakami S, Fujii Y \& Winters SJ 2001 Follistatin production by skin fibroblasts and its regulation by dexamethasone. Molecular and Cellular Endocrinology 172 157-167.

Kawakami S, Fujii Y, Okada Y \& Winters SJ 2002 Paracrine regulation of FSH by follistatin in folliculostellate cell-enriched primate pituitary cell cultures. Endocrinology 143 2250-2258. 
Ketelslegers JM, Hetzel WD, Sherins RJ \& Catt KJ 1978 Developmental changes in testicular gonadotropin receptors: plasma gonadotropins and plasma testosterone in the rat. Endocrinology 103 $212-222$.

Khurshid S, Weinbauer GF \& Nieschlag E 1991 Effect of administration of testosterone and gonadotrophin-releasing hormone $(\mathrm{GnRH})$ antagonist on basal and $\mathrm{GnRH}$-stimulated gonadotrophin secretion in orchidectomized monkeys. Journal of Endocrinology $129363-370$

Kirk SE, Dalkin AC, Yasin M, Haisenleder DJ \& Marshall JC 1994 Gonadotropin-releasing hormone pulse frequency regulates expression of pituitary follistatin messenger ribonucleic acid: a mechanism for differential gonadotrope function. Endocrinology $135876-880$.

Kogure K, Zhang YQ, Kanzaki M, Omata W, Mine T \& Kojima I 1996 Intravenous administration of follistatin: delivery to the liver and effect on liver regeneration after partial hepatectomy. Hepatology 24 361-366.

Krsmanovic LZ, Martinez-Fuentes AJ, Arora KK, Mores N, Tomic M, Stojilkovic SS \& Catt KJ 2000 Local regulation of gonadotroph function by pituitary gonadotropin-releasing hormone. Endocrinology 141 1187-1195.

Kumar TR \& Low MJ 1995 Hormonal regulation of human follicle-stimulating hormone-beta subunit gene expression: $\mathrm{GnRH}$ stimulation and GnRH-independent androgen inhibition. Neuroendocrinology 61 628-637.

Kumar TR, Agno J, Janovick JA, Conn PM \& Matzuk MM 2003 Regulation of FSHbeta and $\mathrm{GnRH}$ receptor gene expression in activin receptor II knockout male mice. Molecular and Cellular Endocrinology 212 19-27.

Labrie F, Drouin J, Ferland L, Lagace L, Beaulieu M, De Lean A, Kelly PA, Caron MG \& Raymond V 1978 Mechanism of action of hypothalamic hormones in the anterior pituitary gland and specific modulation of their activity by sex steroids and thyroid hormones. Recent Progress in Hormone Research 34 25-93.

Leblanc P, L'Heritier A \& Kordon C 1997 Cryptic gonadotropin-releasing hormone receptors of rat pituitary cells in culture are unmasked by epidermal growth factor. Endocrinology 138 574-579.

Lee BL, Unabia G \& Childs G 1993 Expression of follistatin mRNA by somatotropes and mammotropes early in the rat estrous cycle. Journal of Histochemistry and Cytochemistry 41 955-960.

Leung K, Kaynard AH, Negrini BP, Kim KE, Maurer RA \& Landefeld TD 1987 Differential regulation of gonadotropin subunit messenger ribonucleic acids by gonadotropin-releasing hormone pulse frequency in ewes. Molecular Endocrinology 1 724-728.

Ling N, Ying SY, Ueno N, Shimasaki S, Esch F, Hotta M \& Guillemin R 1986 A homodimer of the beta-subunits of inhibin A stimulates the secretion of pituitary follicle stimulating hormone. Biochemical and Biophysical Research Communications 138 1129-1137.

McArdle CA, Poch A \& Kappler K 1993 Cyclic guanosine monophosphate production in the pituitary: stimulation by C-type natriuretic peptide and inhibition by gonadotropin-releasing hormone in alpha T3-1 cells. Endocrinology 132 2065-2072.

McCullagh DR 1932 Dual endocrine activity of the testes. Science 76 19-20.

McLachlan RI, Dahl KD, Bremner WJ, Schwall R, Schmelzer CH, Mason AJ \& Steiner RA 1989 Recombinant human activin-A stimulates basal FSH and $\mathrm{GnRH}$-stimulated $\mathrm{FSH}$ and $\mathrm{LH}$ release in the adult male macaque. Macaca fascicularis. Endocrinology 125 2787-2789.

Majumdar SS, Mikuma N, Ishwad PC, Winters SJ, Attardi BJ, Perera AD \& Plant TM 1995 Replacement with recombinant human inhibin immediately after orchidectomy in the hypophysiotropically clamped male rhesus monkey (Macaca mulatta) maintains folliclestimulating hormone (FSH) secretion and $\mathrm{FSH}$ beta messenger ribonucleic acid levels at precastration values. Endocrinology $\mathbf{1 3 6}$ 1969-1977.

Massague J \& Chen YG 2000 Controlling TGF-beta signaling. Genes and Development 14 627-644.
Masuo Y, Tokito F, Matsumoto Y, Shimamoto N \& Fujino M 1994 Ontogeny of pituitary adenylate cyclase-activating polypeptide (PACAP) and its binding sites in the rat brain. Neuroscience Letters $17043-46$.

Mathews LS \& Vale WW 1991 Expression cloning of an activin receptor, a predicted transmembrane serine kinase. Cell $\mathbf{6 5}$ 973-982.

Matzuk MM, Kumar TR \& Bradley A 1995 Different phenotypes for mice deficient in either activins or activin receptor type II. Nature 374 356-360.

Maurer RA, Kim KE, Schoderbek WE, Roberson MS \& Glenn DJ 1999 Regulation of glycoprotein hormone alpha-subunit gene expression. Recent Progress in Hormone Research 54 455-484 (discussion 485).

Medhamurthy R, Culler MD, Gay VL, Negro-Vilar A \& Plant TM 1991 Evidence that inhibin plays a major role in the regulation of follicle-stimulating hormone secretion in the fully adult male rhesus monkey (Macaca mulatta). Endocrinology 129 389-395.

Merry BJ \& Holehan AM 1981 Serum profiles of LH, FSH, testosterone and 5 alpha-DHT from 21 to 1000 days of age in ad libitum fed and dietary restricted rats. Experimental Gerontology 16 431-444.

Mittler JC 1974 Androgen effects on follicle-stimulating hormone (FSH) secretion in organ culture. Neuroendocrinology $\mathbf{1 6}$ $265-272$.

Miyamoto S, Irahara M, Ushigoe K, Kuwahara A, Sugino H \& Aono T 1999 Effects of activin on hormone secretion by single female rat pituitary cells: analysis by cell immunoblot assay. Journal of Endocrinology 161 375-382.

Moore JP Jr, Wilson L, Dalkin AC \& Winters SJ 2003 Differential expression of the pituitary gonadotropin subunit genes during male rat sexual maturation: reciprocal relationship between hypothalamic pituitary adenylate cyclase-activating polypeptide and folliclestimulating hormone beta expression. Biology of Reproduction 69 234-241.

Nakamura T, Takio K, Eto Y, Shibai H, Titani K \& Sugino H 1990 Activin-binding protein from rat ovary is follistatin. Science $\mathbf{2 4 7}$ 836-838.

Norwitz ER, Xu S, Jeong KH, Bedecarrats GY, Winebrenner LD, Chin WW \& Kaiser UB 2002a Activin A augments GnRH-mediated transcriptional activation of the mouse GnRH receptor gene. Endocrinology 143 985-997.

Norwitz ER, Xu S, Xu J, Spiryda LB, Park JS, Jeong KH, McGee EA \& Kaiser UB 2002 $b$ Direct binding of AP-1 (Fos/Jun) proteins to a SMAD binding element facilitates both gonadotropin-releasing hormone $(\mathrm{GnRH})$ - and activin-mediated transcriptional activation of the mouse GnRH receptor gene. Journal of Biological Chemistry $27737469-37478$.

O'Conner JL, Wade MF, Brann DW \& Mahesh VB 1993 Direct anterior pituitary modulation of gonadotropin secretion by neuropeptide Y: role of gonadal steroids. Neuroendocrinology $\mathbf{5 8}$ 129-135.

Okada Y, Fujii Y, Moore JP Jr \& Winters SJ 2003 Androgen receptors in gonadotrophs in pituitary cultures from adult male monkeys and rats. Endocrinology 144 267-273.

Pangas SA \& Woodruff TK 2000 Activin signal transduction pathways. Trends in Endocrinology and Metabolism 11 309-314.

Payne AH, Kelch RP, Murono EP \& Kerlan JT 1977 Hypothalamic, pituitary and testicular function during sexual maturation of the male rat. Journal of Endocrinology 72 17-26.

Pernasetti F, Vasilyev VV, Rosenberg SB, Bailey JS, Huang HJ, Miller WL \& Mellon PL 2001 Cell-specific transcriptional regulation of follicle-stimulating hormone-beta by activin and gonadotropinreleasing hormone in the LbetaT2 pituitary gonadotrope cell model. Endocrinology 142 2284-2295.

Phillips DJ \& de Kretser DM 1998 Follistatin: a multifunctional regulatory protein. Frontiers in Neuroendocrinology 19 287-322. 
Picanco-Diniz DL, Favaretto AL \& Antunes-Rodrigues J 1996 On the purinergic regulation of hormonal secretion from the anterior pituitary gland. Revista Brasileira de Biologia 56 369-372.

Pincas H, Laverriere JN \& Counis R 2001 Pituitary adenylate cyclaseactivating polypeptide and cyclic adenosine $3^{\prime}, 5^{\prime}$-monophosphate stimulate the promoter activity of the rat gonadotropin-releasing hormone receptor gene via a bipartite response element in gonadotrope-derived cells. Journal of Biological Chemistry 276 $23562-23571$.

Plant TM \& Dubey AK 1984 Evidence from the rhesus monkey (Macaca mulatta) for the view that negative feedback control of luteinizing hormone secretion by the testis is mediated by a deceleration of hypothalamic gonadotropin-releasing hormone pulse frequency. Endocrinology 115 2145-2153.

Rivier C, Cajander S, Vaughan J, Hsueh AJ \& Vale W 1988 Agedependent changes in physiological action, content, and immunostaining of inhibin in male rats. Endocrinology 123 120-126.

Roberts V, Meunier H, Vaughan J, Rivier J, Rivier C, Vale W \& Sawchenko P 1989 Production and regulation of inhibin subunits in pituitary gonadotropes. Endocrinology 124 552-554.

Robertson DM, Klein R, de Vos FL, McLachlan RI, Wettenhall RE, Hearn MT, Burger HG \& de Kretser DM 1987 The isolation of polypeptides with FSH suppressing activity from bovine follicular fluid which are structurally different to inhibin. Biochemical and Biophysical Research Communications 149 744-749.

Robertson D, Burger HG, Sullivan J, Cahir N, Groome N, Poncelet E, Franchimont P, Woodruff T \& Mather JP 1996 Biological and immunological characterization of inhibin forms in human plasma. Journal of Clinical Endocrinology and Metabolism 81 669-676.

Rodin DA, Lalloz MR \& Clayton RN 1989 Gonadotropin-releasing hormone regulates follicle-stimulating hormone beta-subunit gene expression in the male rat. Endocrinology 125 1282-1289.

Rodin DA, Abbot SD, Saade G \& Clayton RN 1990 Comparison of the pretranslational regulation of FSH synthesis by gonadal steroids in rats and mice. Journal of Molecular Endocrinology 4 159-167.

Rosenfeld MG, Briata P, Dasen J, Gleiberman AS, Kioussi C, Lin C, O'Connell SM, Ryan A, Szeto DP \& Treier M 2000 Multistep signaling and transcriptional requirements for pituitary organogenesis in vivo. Recent Progress in Hormone Research 55 1-13 (discussion 13-14).

Schlatt S, Weinbauer GF \& Nieschlag E 1991 Inhibin-like and gonadotropin-like immunoreactivity in pituitary cells of male monkeys (Macaca fascicularis, Macaca mulatta). Cell Tissue Research 265 203-209.

Shamgochian MD \& Leeman SE 1992 Substance P stimulates luteinizing hormone secretion from anterior pituitary cells in culture. Endocrinology $131871-875$.

Sharpe RM, Turner KJ, McKinnell C, Groome NP, Atanassova N, Millar MR, Buchanan DL \& Cooke PS 1999 Inhibin B levels in plasma of the male rat from birth to adulthood: effect of experimental manipulation of Sertoli cell number. Journal of Andrology 20 94-101.

Sheridan R, Loras B, Surardt L, Ectors F \& Pasteels JL 1979 Autonomous secretion of follicle-stimulating hormone by long term organ cultures of rat pituitaries. Endocrinology 104 198-204.

Skoglosa Y, Takei N \& Lindholm D 1999 Distribution of pituitary adenylate cyclase activating polypeptide mRNA in the developing rat brain. Brain Research. Molecular Brain Research 65 1-13.

Soji T, Mabuchi Y, Kurono C \& Herbert DC 1997 Folliculo-stellate cells and intercellular communication within the rat anterior pituitary gland. Microscopy Research and Technique 39 138-149.

Spady TJ, Shayya R, Thackray VG, Ehrensberger L, Bailey JS \& Mellon PL 2004 Androgen regulates FSH $\beta$ gene expression in an activin-dependent manner in immortalized gonadotropes. Molecular Endocrinology 18 925-940.

Spratt DI, Finkelstein JS, Butler JP, Badger TM \& Crowley WF Jr 1987 Effects of increasing the frequency of low doses of gonadotropin-releasing hormone $(\mathrm{GnRH})$ on gonadotropin secretion in
GnRH-deficient men. Journal of Clinical Endocrinology and Metabolism 64 1179-1186.

Stojilkovic SS \& Catt KJ 1995 Expression and signal transduction pathways of gonadotropin-releasing hormone receptors. Recent Progress in Hormone Research 50 161-205.

Suszko MI, Lo DJ, Suh H, Camper SA \& Woodruff TK 2003 Regulation of the rat follicle-stimulating hormone beta-subunit promoter by activin. Molecular Endocrinology 17 318-332.

Swerdloff RS, Walsh PC, Jacobs HS \& Odell WD 1971 Serum LH and FSH during sexual maturation in the male rat: effect of castration and cryptorchidism. Endocrinology 88 120-128.

Swerdloff RS, Grover PK, Jacobs HS \& Bain J 1973 Search for a substance which selectively inhibits FSH - effects of steroids and prostaglandins on serum FSH and $\mathrm{LH}$ levels. Steroids $\mathbf{2 1}$ $703-722$.

Tang K, Bartke A, Gardiner CS, Wagner TE \& Yun JS 1993 Gonadotropin secretion, synthesis, and gene expression in two types of bovine growth hormone transgenic mice [erratum appears in Biology of Reproduction 199349 865]. Biology of Reproduction $49346-353$.

Todd JF, Small CJ, Akinsanya KO, Stanley SA, Smith DM \& Bloom SR 1998 Galanin is a paracrine inhibitor of gonadotroph function in the female rat. Endocrinology $1394222-4229$.

Tomic M, Jobin RM, Vergara LA \& Stojilkovic SS 1996 Expression of purinergic receptor channels and their role in calcium signaling and hormone release in pituitary gonadotrophs. Integration of P2 channels in plasma membrane- and endoplasmic reticulumderived calcium oscillations. Journal of Biological Chemistry 271 21200-21208.

Tsujii T, Ishizaka K \& Winters SJ 1994 Effects of pituitary adenylate cyclase-activating polypeptide on gonadotropin secretion and subunit messenger ribonucleic acids in perifused rat pituitary cells. Endocrinology 135 826-833.

Tsujii T, Attardi B \& Winters SJ 1995 Regulation of alpha-subunit mRNA transcripts by pituitary adenylate cyclase-activating polypeptide (PACAP) in pituitary cell cultures and alpha T3-1 cells. Molecular and Cellular Endocrinology 113 123-130.

Uccella S, La Rosa S, Genasetti A \& Capella C 2000 Localization of inhibin/activin subunits in normal pituitary and in pituitary adenomas. Pituitary 3 131-139.

Ueno N, Ling N, Ying SY, Esch F, Shimasaki S \& Guillemin R 1987 Isolation and partial characterization of follistatin: a single-chain Mr 35,000 monomeric protein that inhibits the release of folliclestimulating hormone. PNAS 84 8282-8286.

Vale W, Rivier J, Vaughan J, McClintock R, Corrigan A, Woo W, Karr D \& Spiess J 1986 Purification and characterization of an FSH releasing protein from porcine ovarian follicular fluid. Nature 321 $776-779$.

Vale W, Rivier C, Hsueh A, Campen C, Meunier H, Bicsak T et al. 1988 Chemical and biological characterization of the inhibin family of protein hormones. Recent Progress in Hormone Research $441-34$.

Weiss J, Crowley WF Jr, Halvorson LM \& Jameson JL 1993 Perifusion of rat pituitary cells with gonadotropin-releasing hormone, activin, and inhibin reveals distinct effects on gonadotropin gene expression and secretion. Endocrinology 132 2307-2311.

Weiss J, Guendner MJ, Halvorson LM \& Jameson JL 1995 Transcriptional activation of the follicle-stimulating hormone beta-subunit gene by activin. Endocrinology 136 1885-1891.

Wildt L, Hausler A, Marshall G, Hutchison JS, Plant TM, Belchetz PE \& Knobil E 1981 Frequency and amplitude of gonadotropin-releasing hormone stimulation and gonadotropin secretion in the rhesus monkey. Endocrinology 109 376-385.

Winters SJ 1994 FSH is produced by GnRH-deficient men and is suppressed by testosterone. Journal of Andrology 15 216-219.

Winters SJ \& Plant TM 1999 Partial characterization of circulating inhibin-B and pro-alphaC during development in the male rhesus monkey. Endocrinology 140 5497-5504. 
Winters SJ, Pohl CR, Adedoyin A \& Marshall GR 1996 Effects of continuous inhibin administration on gonadotropin secretion and subunit gene expression in immature and adult male rats. Biology of Reproduction 55 1377-1382.

Winters SJ, Dalkin AC \& Tsujii T 1997 Evidence that pituitary adenylate cyclase activating polypeptide suppresses follicle-stimulating hormone-beta messenger ribonucleic acid levels by stimulating follistatin gene transcription. Endocrinology 138 4324-4329.

Winters SJ, Kawakami S, Sahu A \& Plant TM 2001 Pituitary follistatin and activin gene expression, and the testicular regulation of FSH in the adult Rhesus monkey (Macaca mulatta). Endocrinology 142 2874-2878.

Woodruff TK, Besecke LM, Groome N, Draper LB, Schwartz NB \& Weiss J 1996 Inhibin A and inhibin B are inversely correlated to follicle-stimulating hormone, yet are discordant during the follicular phase of the rat estrous cycle, and inhibin $A$ is expressed in a sexually dimorphic manner. Endocrinology 137 5463-5467.

Xu J, McKeehan K, Matsuzaki K \& McKeehan WL 1995 Inhibin antagonizes inhibition of liver cell growth by activin by a dominant-negative mechanism. Journal of Biological Chemistry 270 6308-6313.

Ying SY 1988 Inhibins, activins, and follistatins: gonadal proteins modulating the secretion of follicle-stimulating hormone. Endocrine Reviews 9 267-293.

Yu WH, Kimura M, Walczewska A, Porter JC \& McCann SM 1998 Adenosine acts by $\mathrm{A} 1$ receptors to stimulate release of prolactin from anterior-pituitaries in vitro. PNAS 95 7795-7798.

Zapatero-Caballero H, Sanchez-Franco F, Guerra-Perez N, Fernandez-Mendez C \& Fernandez-Vazquez G 2003 Gonadotropin-releasing hormone receptor gene expression during pubertal development of male rats. Biology of Reproduction $\mathbf{6 8}$ $1764-1770$. 